\title{
Ion Pair-Dispersive Liquid-Liquid Microextraction Coupled to Microsample Injection System-Flame Atomic Absorption Spectrometry for Determination of Gold at Trace Level in Real Samples
}

\author{
Aysen Hol, ${ }^{1}$ Aslıhan Arslan Kartal, ${ }^{2}$ Abdullah Akdogan, ${ }^{2}$ Aydan Elçi, ${ }^{3}$ \\ Tuba Arslan, ${ }^{1}$ and Latif Elçi ${ }^{1}{ }^{1 *}$ \\ ${ }^{1}$ Department of Chemistry, Faculty of Science and Art, Pamukkale University, Denizli 20017, Turkey \\ ${ }^{2}$ Department of Chemistry and Chemical Process Technology, Denizli Vocational School \\ of Technical Sciences, Pamukkale University, Denizli 20017, Turkey \\ ${ }^{3}$ Department of Chemistry, Faculty of Sciences, University of Ege, Bornova 35040, Turkey \\ * Corresponding author: E-mail: elci@ pau.edu.tr
}

Received: 11-08-2014

\begin{abstract}
A novel ion pair-dispersive liquid-liquid microextraction (IP-DLLME) of gold followed by its determination with microsample injection system - flame atomic absorption spectrometry (MIS-FAAS) was developed. The extraction method was based on the reaction of anionic tetrachloro gold(III) complex with the cationic form of Rhodamine B to give a violet ion pair complex, which is extracted from $1.0 \mathrm{~mol} \mathrm{~L}^{-1} \mathrm{HCl}$ solution of $8.0 \mathrm{~mL}$ to fine droplets of chloroform of $500 \mu \mathrm{L}$. A Plackett-Burman experimental design of MINITAB statistical program was employed to optimize the influence of main parameters to be controlled in DLLME. After optimizing the extraction conditions, gold was quantitatively recovered by preconcentration factor 40 , limit of detection (LOD) $1.8 \mu \mathrm{g} \mathrm{L}^{-1}$ and relative standard deviation less than $6.8 \%$. The proposed method was successfully applied to the preconcentration and determination of gold in some samples such as tap water, waste water, copper electrolysis solution and copper wire coated with nickel.
\end{abstract}

Keywords: Gold, dispersive liquid-liquid microextraction, Rhodamine B, experimental design, MIS-AAS, water and copper samples.

\section{Introduction}

Gold, one of the most important noble metals, is extensively used in various areas, mostly in jewellery, electroplating, petrochemistry, microelectronics and nuclear power industries, and is mostly utilized in biology, medicine and chemistry nowadays. ${ }^{1}$ Due to extensive use of gold and gold compounds, gold is also released to the environment through industrial wastes. The concentration of gold in environmental samples is extremely in low level, as $0.05 \mathrm{ng} \mathrm{mL}^{-1}, 0.2 \mathrm{ng} \mathrm{mL}^{-1}$ and $1 \mathrm{ng} \mathrm{g}^{-1}$ have been reported for seawater, river water and soil samples, respectively. ${ }^{2}$ Thus an accurate, sensitive and selective analytical method is required for gold determination. A wide variety of analytical techniques such as flame ato- mic absorption spectrometry (FAAS), ${ }^{3,4}$ electrothermal atomic absorption spectrometry (ETAAS), ${ }^{5,6}$ inductively coupled plasma atomic emission spectrometry (ICPAES) $)^{7,8}$ and spectrophotometry ${ }^{9,10}$ to determine gold have been explained. The direct determination of gold by most of the analytical techniques suggested is to extend some problems becasue of the interfering matrix components at high concentrations in several real samples, therefore, an effective sample pretreatment step, such as preconcentration of the analyte and matrix isolation, are still necessary to obtain reliable results. Many preconcentration and separation methods have been frequently carried out using liquid-liquid ${ }^{11-13}$ and liquid-solid extractions. ${ }^{1,3-5,9,10,14}$ 
However, it should be pointed out that the conventional preconcentration methods are nowadays not recommended because of large volume of organic solvent and their multiple steps. Thus, the miniaturized preconcentration methods have been developed. Among these methods, dispersive liquid-liquid microextraction (DLLME) recently introduced by Assadi and co-workers ${ }^{15}$ has become increasingly popular in comparison with the conventional extraction methods. ${ }^{16}$ DLLME developed initially for the extraction of organic compounds has been applied to extraction and preconcentration of many metal ions. ${ }^{17}$ DLLME papers related to metal ions report the use of chelating ligands, ion-pair reagents and ligandless-dispersive liquid-liquid microextraction. The ion-pair-DLLME (IPDLLME) has been employed for gold following the formation of an ion pair complex between the $\mathrm{AuCl}_{4}^{-}$complex and different counter ions such as amiloride mono hydrochloride, ${ }^{18}$ victoria blue $\mathrm{R},{ }^{19}$ dicyclohexylamine, ${ }^{6}$ and benzyldimethyltetradecyl-ammoniumchloride ${ }^{20}$. For many years, it has been well-known that gold is determined using a spectrophotometric method based on the reaction of $\mathrm{AuCl}_{4}^{-}$with the cationic form of Rhodamine $\mathrm{B}$ to give a violet ion pair complex. ${ }^{21,22}$ However, literature review has reported no study on the application of Rhodamine B for IP-DLLME of $\mathrm{Au}(\mathrm{III})$ ions.

On the other hand, to achive the high preconcentration factor by DLLME as a miniaturized preconcentration technique, it is concluded that its combination with a microsampling measurement technique is a very significant point. Recently, we have showed that the innovative microsample injection system (MIS) has provided an opportunity to analyze a small volume of sample, e.g. $100 \mu \mathrm{L}$, by flame atomic absorption spectrometry with high accuracy and reproducibility. ${ }^{23}$ However, there was no the report of the use of IP-DLLME method with microsample injection system coupled to flame atomic absorption spectrophotometry (MIS-FAAS) for the determination of gold. Therefore, in this study, we combined IP-DLLME with MIS-FAAS to develop a novel method for preconcentration and determination of $\mathrm{Au}(\mathrm{III})$ ions.

The purpose of this paper is to demonstrate the usefulness of IP-DLLME combined with MIS-FAAS for the determination of gold in some samples. The IP-DLLME technique was used with an appropriate mixture of chloroform (extraction solvent), ethanol (dispersive solvent) and Rhodamine B (ion-pair agent) to preconcentrate gold from aqueous samples.

\section{Experimental}

\section{1. Instruments}

A flame atomic absorption spectrometer (PerkinElmer, AAnalyst 200) equipped with a deuterium-lamp background corrector and an air-acetylene burner was used for determination of gold. Absorbances were measu- red as the peak height by a microsample injection system coupled with flame atomic absorption spectrophotometry (MIS-FAAS). The instrumental settings were as follows: wavelength $242.8 \mathrm{~nm}$; slit width $1.0 \mathrm{~nm}$; lamp current 4 $\mathrm{mA}$; acetylene flow $1.5 \mathrm{~L} \mathrm{~min}^{-1}$ and air flow $3.5 \mathrm{~L} \mathrm{~min}^{-1}$. The injection system was coupled to the nebulizer needle using a PTFE capillary tube attached with a micropipette tip as reported in our previous study. ${ }^{23}$ Aliquots of $100 \mu \mathrm{L}$ for all samples and calibration solutions were injected directly into the microsample injection system. The $\mathrm{pH}$ values of aqueous phase were controlled by a Hanna pH 211 Model with a glass-electrode supplied with a combined glass-electrode.

\section{2. Reagent and Solutions}

All chemicals were of analytical-reagent grade (Merck, Darmstadt, Gemany). Ultrapure quality water (resistivity $18.2 \mathrm{M} \Omega \mathrm{cm}^{-1}$ ) used throughout the experiments was obtained by reverse osmosis system (Human Corp., Seoul, Korea).

The working and reference solutions were prepared daily by the dilution of commercial stock solutions (1000 $\pm 4.0 \mathrm{mg} \mathrm{L}^{-1}$ ) of gold purchased from Fluka, Germany.

Rhodamine B solution $\left(5.8 \times 10^{-5} \mathrm{~mol} \mathrm{~L}^{-1}\right)$ was prepared by dissolving solid Rhodamine B (Merck) in chloroform. The Rhodamine B solution was prepared freshly.

$0.1 \mathrm{~mol} \mathrm{~L}^{-1} \mathrm{HCl}$ solution was prepared from concentrated $\mathrm{HCl}(\mathrm{d} 1,18 \mathrm{~g} / \mathrm{mL}, 37 \%)$ purchased from Sigma Aldrich.

The laboratory glassware and conical-bottom polypropylene tube were kept overnight in a $10 \% \mathrm{HCl}$ solution. Before use, all of the glassware and conical-bottom polypropylene tube were washed with UP water and dried.

\section{3. General Procedure for DLLME}

Eight $\mathrm{mL}$ of $1.0 \mathrm{~mol} \mathrm{~L}^{-1} \mathrm{HCl}$ solution containing $0.20 \mu \mathrm{g} \mathrm{Au}(\mathrm{III})$ ions was transferred into a $15 \mathrm{~mL}$ PTFE tube with conical bottom, and then a mixture of $500 \mu \mathrm{L}$ $\mathrm{CHCl}_{3}$ and $1 \mathrm{~mL}$ acetone containing $10 \mu \mathrm{g}$ Rhodamine B was added quickly to this solution by using a $2.0 \mathrm{~mL}$ syringe. The resulting cloudy solution was vortexed for $1.0 \mathrm{~min}$ at $1600 \mathrm{rpm}$ and then centrifuged at $3000 \mathrm{rpm}$ for three minutes. After centrifugation, the upper aqueous phase was removed with a dropper. The organic phase remaining at the bottom of the tube was evaporated on a water bath for about $3 \mathrm{~min}$. The residue was dissolved in 200 $\mu \mathrm{L}$ UP water containing $50 \mu \mathrm{L}$ concentrated $\mathrm{HNO}_{3}$. The evaporation and dissolution steps are necessary in order to remove the viscous organic phase and facilitate sample handling prior to a microsample injection system coupled with flame atomic absorption spectrophotometric determination. Gold content of the final solution was determined by MIS-FAAS. 


\section{4. Sample Preparation and Real Sample Analysis}

Tap water was taken from drinking water system of Bornova-Izmir, Turkey and then analysed without pretreatment, using the general procedure.

Waste water sample was collected from inlet of the municipal wastewater treatment plant in Denizli City, Turkey. The water sample was brought to the laboratory in one hour and filtered through $0.45-\mu \mathrm{m}$ cellulose nitrate membranes (Sartorius, GmbH, Germany) under vacuum to eliminate suspended matter. On the same day, it was acidified to $1 \mathrm{~mol} \mathrm{~L}^{-1} \mathrm{HCl}$ with convenient volume of concentrated $\mathrm{HCl}$ and then analysed by the general procedure above.

A nickel-plated wire sample was obtained from ERBAKIR company in Denizli. For the wire analysis, 0.0136 $\mathrm{g}$ wire sample was dissolved in $0.50 \mathrm{~mL}$ of concentrated $\mathrm{HNO}_{3}$. The solution was evaporated to almost dryness and then diluted to $100 \mathrm{~mL}$ with $1 \mathrm{~mol} \mathrm{~L}^{-1} \mathrm{HCl}$. The general procedure above was applied to this solution.

The electrolyte solution from copper electrolysis unit of ER-BAKIR company in Denizli, Turkey was obtained and then diluted 200-fold by UP water before the analysis because of high copper ion concentration, i.e. $7210 \mathrm{mg} / \mathrm{L} \mathrm{Cu}$. The diluted sample was analysed by the general procedure.

\section{5. Optimization Strategy}

In this study, the experimental design analysis and data processing were carried out using the MINITAB 13.1 statistical software package. There are several factors, such as extraction solvent type and volume, dispersive solvent type and volume, sample volume, concentration of $\mathrm{HCl}$ and ligand amount that affect the extraction process. To optimize the experimental conditions of DLLME for extraction of $\mathrm{Au}(\mathrm{III})$ ions, the full factorial and PlackettBurman designs were used for screening the variables.

\section{Results and Discussion}

\section{1. Optimization of The Main Microextraction Parameters}

\section{1. 1. Factorial Design}

The full factorial design was developed in order to identify the types of dispersive solvent and extraction sol-

Table 1. The design variables, low and high levels in $2^{2}$ full factorial design matrix

\begin{tabular}{lcc}
\hline Factors & Low (-) & Levels \\
\hline Extraction solvent & Chlorobenzene & High (+) \\
Dispersive solvent & Ethanol & Acetone \\
\hline
\end{tabular}

vent. The high and low levels defined for the $2^{2}$ factorial design are listed in Table 1. The low and high levels for the factors were chosen based on the previous experiments.

The factorial design matrix and recovery of $\mathrm{Au}(\mathrm{III})$ ions in each factorial experiment are shown in Table 2, with the low (-) and high (+) levels as specified in Table 1. All the experiments for $\mathrm{Au}(\mathrm{III})$ ions were carried out in four replicates. The order in which the experiments were made was randomized to avoid systematic errors.

Table 2. Design matrix and the results of the $2^{2}$ full factorial design

\begin{tabular}{cccc}
\hline $\begin{array}{c}\text { Experiment } \\
\text { no }\end{array}$ & $\begin{array}{c}\text { Extraction } \\
\text { solvent }\end{array}$ & $\begin{array}{c}\text { Dispersive } \\
\text { solvent }\end{array}$ & $\begin{array}{c}\text { Recovery, } \\
\%\end{array}$ \\
\hline 1 & + & + & $96 \pm 4$ \\
2 & - & + & $49 \pm 6$ \\
3 & - & - & $30 \pm 4$ \\
4 & + & - & $48 \pm 2$ \\
\hline
\end{tabular}

As seen from the Table 2, the highest recovery value of $\mathrm{Au}(\mathrm{III})$ ions was obtained in experiment 1. The quantitative recovery $(\geq 95 \%)$ related with the design was obtained with the high level of factors. Thus, in the preconcentration of $\mathrm{Au}$ (III) ions by dispersive liquid-liquid microextraction, chloroform and acetone were selected as extraction solvent and dispersive solvent, respectively.

In the next step, after identifying types of extraction solvent and dispersive solvent, the effective parameters of DLLME such as volume of extraction and dispersive solvents, concentration of $\mathrm{HCl}$ and Rhodamine B amount were evaluated by a Plackett Burman design to identify

Table 3. The design variables, low and high levels and design matrix in Plackett-Burman design

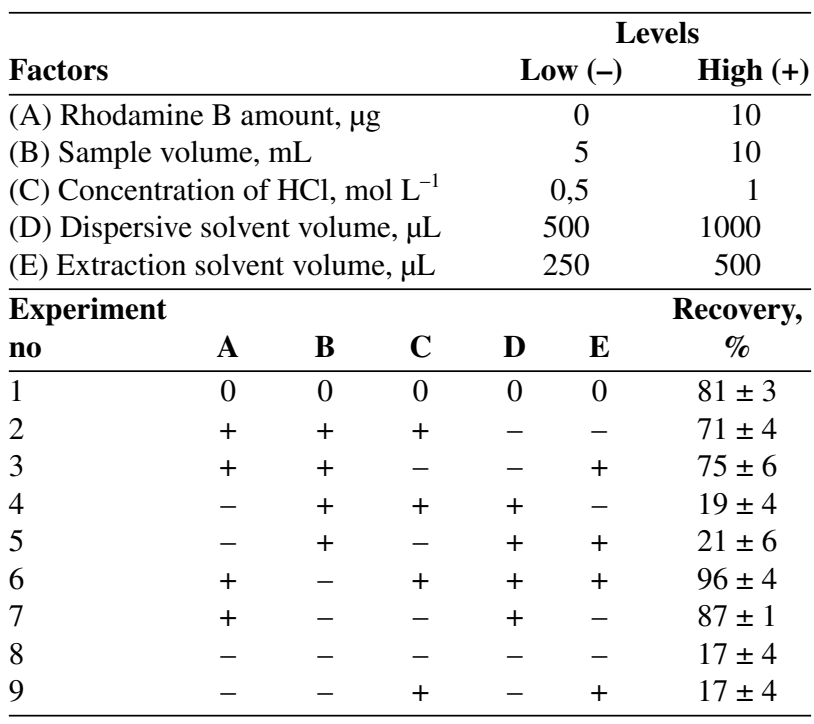

0: Central Point 
the most important parameters and their interactions. The factors selected and their levels are presented in Table 3. The factors and their levels were selected according to the available data and experience gathered in previous screening experiments. A factorial Plackett Burman $2^{5-2}$ experimental design with one centerpoint which studied the effects of the five factors in 9 experiments was run. The Plackett Burman design matrix and recovery of $\mathrm{Au}(\mathrm{III})$ ions in each factorial experiment are shown in Table 3. As seen from Table 3 , in the experiment 6 , the quantative recovery was obtained for Au. Thus, amount of Rhodamine B of $10 \mu \mathrm{g}$, concentration of $\mathrm{HCl} 1.0 \mathrm{~mol} \mathrm{~L}^{-1}$, dispersive solvent (acetone) volume $1000 \mu \mathrm{L}$ and extraction solvent (chloroform) volume $500 \mu \mathrm{L}$ were selected. Although the sample volume was chosen as $5 \mathrm{~mL}$, it was studied again to obtain high preconcentration factor.

\section{1. 2. The Main Effects}

The main effects plot was generated to represent the results of the regression analysis. It shows only the factors that are significant at the $95 \%$ confidence interval. The main effects represent deviations of the average between the high and low levels for each factor. The main effects of each parameter on the recovery of gold are shown in Fig. 1. When the effect of a factor is positive, recovery of gold $(\% \mathrm{R})$ increases as the factor changes from low to high levels. In contrast, if the effects are negative, a reduction on recovery of gold occurs for high level of the same factor. ${ }^{24,25}$ From Fig. 1, it is inferred that the longer the vertical line, the larger the change on recovery of $\mathrm{Au}$ when changing from low level to high level. It should be pointed out that the statistical significance of a factor is directly related to the length of the vertical line. ${ }^{26}$ The effects of all factors are positive, meaning that an increase of recovery is observed when the factor changes from low to high.

\section{1. 3. The Pareto Chart}

The results of the experimental design were evaluated by an analysis of variance test at a 5\% significan-

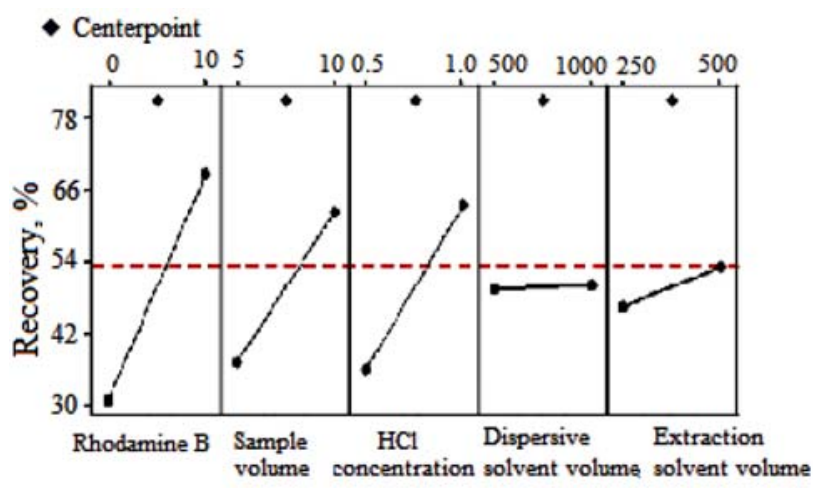

Figure 1. Main effects plot for recovery of gold ce level, and the main effects were shown using standardized Pareto charts (Figure 2). The vertical line on the plot judged statistically significant effects. The bar extending beyond the line corresponds to the effects that are statistically significant at the $95 \%$ confidence level. $^{27}$

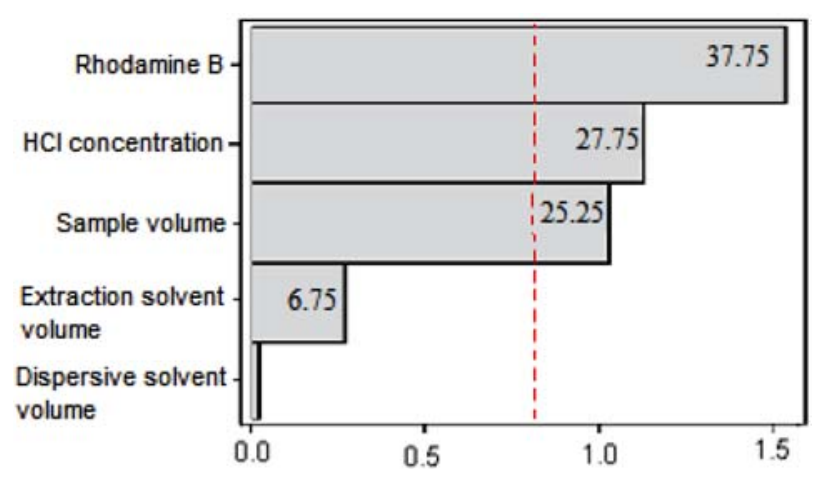

Figure 2. Pareto charts of the main effects obtained from the Plackett Burman design

According to Figure 2, the amount of Rhodamine $\mathrm{B}$ was the most significant factor having a positive effect on the extraction efficiency. Other important factors were $\mathrm{HCl}$ concentration and sample volume on the extraction efficiency of $\mathrm{Au}(\mathrm{III})$ ions, respectively. The Pareto charts indicate that the other two variables (extraction solvent volume and dispersive solvent volume) have no significant effect on the recovery of $\mathrm{Au}$ (III) ions. The positive and negative signs can be enhanced or reduced, respectively, when passing from the lowest to the highest level set for the specific factor. All factors were shown to have a positive effect on the extraction efficiency, in order to achieve high efficieny and good selectivity, amount of Rhodamine B was selected as 10 $\mu \mathrm{g}$, concentration of $\mathrm{HCl}$ as $1.0 \mathrm{~mol} \mathrm{~L}^{-1}$, dispresive solvent volume as $1000 \mu \mathrm{L}$ and extraction solvent volume as $500 \mu \mathrm{L}$. As seen in Figure 2, sample volume was the third most significant factor having a positive effect on the extraction efficiency in this sudy. The high value for sample volume is needed to investigate in detail because of the positive significant effect of sample volume for $\mathrm{Au}(\mathrm{III})$ ions.

\section{2. Effect of Sample Volume}

It has been concluded from the Figures 1 and 2 that it is necessary to evaluate in detail the sample volume. This is important to achieve high preconcentration factor. Thus, the effect of sample volume was checked by changing the range of sample volume from 2.0 to $10.0 \mathrm{~mL}$ (Figure 3). It was found that quantitative recovery $(\geq 95 \%)$ was obtained up to a sample volume of $8.0 \mathrm{~mL}$. 


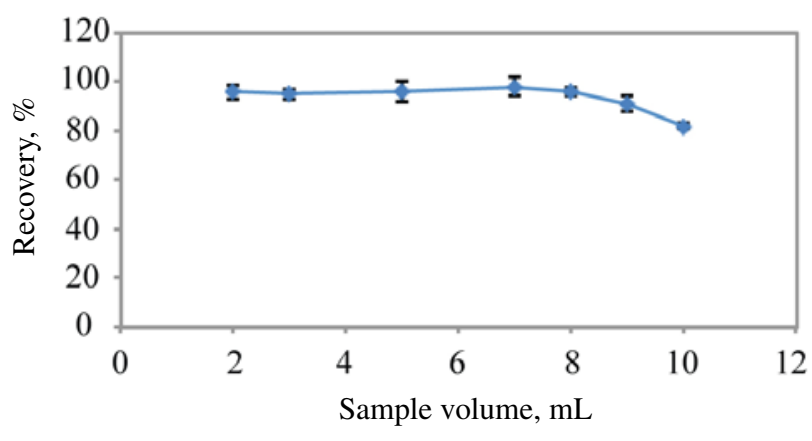

Figure 3. Effect of sample volume on recovery of $10 \mu \mathrm{g} \mathrm{L}^{-1} \mathrm{Au}(\mathrm{III})$ ions as ion pair complex (n:4)

\section{3. Effect of Vortex-Assisted Extraction Time and Centrifuge Time}

In this study, to enhance the extraction efficiency and decrease the time to reach dynamic equilibrium, vortex agitation was used for fast and easy dispersion of the extractant (chloroform) into the aqueous sample solution. After the extractant-dispersive mixture including Rhodamine B as ion pair agent was injected rapidly into the sample solution, a cloudy solution formed was vortexed. For this, vortex rotational speed was fixed at $1600 \mathrm{rpm}$ and the effect of vortexing times was tested in the range of from 0 to 5 min (Table 4). No significant effect was observed at the vortexing time ranging from 1 to $5 \mathrm{~min}$, which indicated that the quantitative analyte transfer and the equilibrium state were achieved in only $1 \mathrm{~min}$. The quantitative recovery $(\geq 95 \%)$ of $\mathrm{Au}(\mathrm{III})$ ions was not obtained without the vortex mixing. The data in Table 4 show that the vortex agitation is necessary for quantitative extraction of $\mathrm{Au}(\mathrm{III})$ ions. Thus, $1 \mathrm{~min}$ was chosen as vortex-assisted extraction time and used for further experiments.

Table 4. Influence of vortex-mixing time on recovery $10 \mu \mathrm{g} \mathrm{L} \mathrm{L}^{-1}$ $\mathrm{Au}(\mathrm{III})$ ions as ion pair complex (sample volume: $8.0 \mathrm{~mL}$, centrifuge time: $3 \mathrm{~min}, \mathrm{n}: 4$ )

\begin{tabular}{cc}
\hline Vortex-mixing time, $\min$ & Recovery, \% \\
\hline 0 & $62.4 \pm 3.7$ \\
0.5 & $77.2 \pm 2.8$ \\
1 & $96.7 \pm 4.1$ \\
2 & $95.4 \pm 3.9$ \\
4 & $98.1 \pm 3.1$ \\
5 & $96.3 \pm 4.4$ \\
\hline
\end{tabular}

After 1 min vortex-assisted extraction time, the mixture was centrifuged immediately to seperate aqueous and extractant phases in the conical tube. The best centrifuge rotational speed was found experimentally as $3000 \mathrm{rpm}$. Furthermore, the effect of centrifuge time on the recovery of $\mathrm{Au}(\mathrm{III})$ ions was evaluated. As seen from Figure 4, after 3 min the quantitative value $(\geq 95 \%)$ was achieved. Therefore, the centrifuge time was chosen as $3 \mathrm{~min}$.

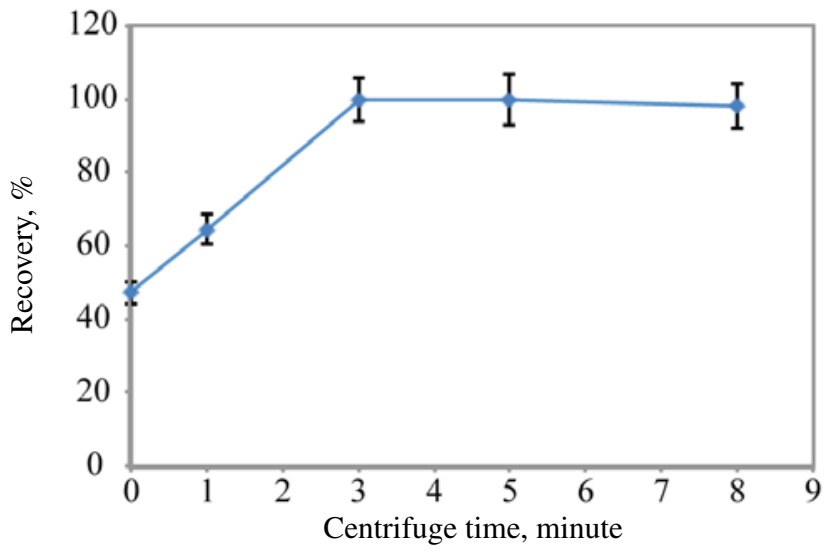

Figure 4. Influence of centrifuge time on recovery of $10 \mu \mathrm{g} \mathrm{L}^{-1}$ $\mathrm{Au}(\mathrm{III})$ ions as ion pair complex (sample volume: $8.0 \mathrm{~mL}$, vortex mixing time: $1 \mathrm{~min}, \mathrm{n}: 4$ )

\section{4. Influence of Salts and Interfering Ions}

The influence of ionic strength was tested by adding the known concentration of $\mathrm{NaCl}$ into the aqueous solutions of $50 \mu \mathrm{g} \mathrm{L} \mathrm{L}^{-1}$ of $\mathrm{Au}(\mathrm{III})$ ions in a concentration range from 0 to $10 \%$, and the rest of the experimental conditions were kept constant. The obtained recoveries showed that the overall process was not affected significantly by $\mathrm{NaCl}$ in the examined concentration range (Figure 5). Thus, for the further study, salt was not added to the sample solution.

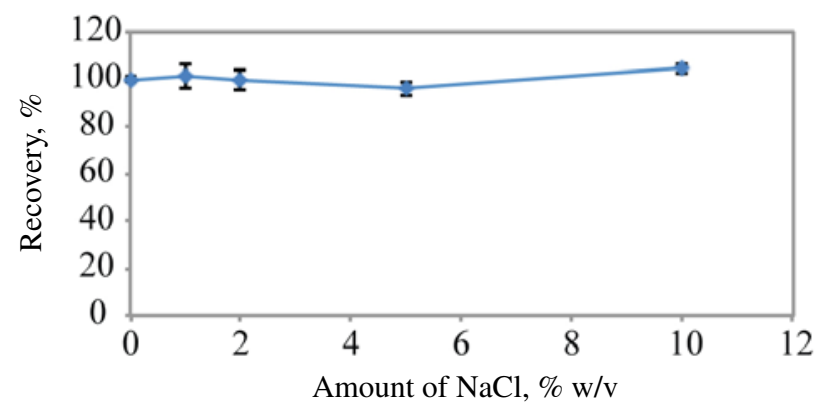

Figure 5. Effect of salt on recovery of $50 \mu \mathrm{g} \mathrm{L} \mathrm{L}^{-1} \mathrm{Au}(\mathrm{III})$ ions as ion pair complex (n:4)

The possible interferences of common coexisting ions on the extraction of $\mathrm{Au}(\mathrm{III})$ ions were investigated to evaluate the selectivity and applicability of the proposed method to real samples. In these experiments, solutions of $50 \mu \mathrm{g} \mathrm{L}^{-1}$ of $\mathrm{Au}(\mathrm{III})$ ions containing the coexisting ions were treated according to the general procedure above. The tolerance limits of the coxisting ions, defined as the largest concentration causing a change in the recovery of $\mathrm{Au}$ (III) ions no higher than 5\%, are given in Table 5. The results show good tolerance to coexisting ions examined in water, electrolysis and nickel wire samples. It is stated that the developed method was applicable to the analysis of real samples. 
Table 5. Tolerable concentration of the interfering ions on the determination of $50 \mu \mathrm{g} \mathrm{L}{ }^{-1} \mathrm{Au}(\mathrm{III})$ ions using IP-DLLME ( $\left.\mathrm{n}=4\right)$

\begin{tabular}{|c|c|}
\hline Interfering ions $\mathrm{s}^{\mathrm{a}}$ & $\begin{array}{l}\text { Maximum tolerable } \\
\text { concentration, } \mathrm{mg} \mathrm{L}^{-1}\end{array}$ \\
\hline$\overline{\mathrm{Na}^{+}}$ & 40000 \\
\hline $\mathrm{K}^{+}$ & 500 \\
\hline $\mathrm{Mg}^{2+}$ & 1000 \\
\hline $\mathrm{Ca}^{2+}, \mathrm{Ba}^{2+}$ & 500 \\
\hline $\mathrm{PO}_{4}{ }^{3-}, \mathrm{CO}_{3}{ }^{2-}$ & 1500 \\
\hline $\mathrm{SO}_{4}^{2-}$ & 3000 \\
\hline $\mathrm{Cl}^{-}$ & 60000 \\
\hline $\mathrm{Cu}^{2+}, \mathrm{Zn}^{2+}$ & 40 \\
\hline $\mathrm{Ni}^{2+}, \mathrm{Cd}^{2+}, \mathrm{Pb}^{2+}, \mathrm{Hg}^{2+}$ & 25 \\
\hline $\mathrm{Fe}^{3+}$ & 15 \\
\hline
\end{tabular}

\section{5. Analytical Performance}

The analytical figures of the proposed procedure were determined under the optimized conditions. The calibration equation obtained by DLLME procedure was found as $\mathrm{A}=2.1253 \mathrm{C}+0.0011$ with a correlation coefficient of 0.9997, in which $\mathrm{A}$ is the absorbance for $\mathrm{Au}(\mathrm{III})$ ions in the enriched phase and $\mathrm{C}$ is the concentration of $\mathrm{Au}(\mathrm{III})$ ions as $\mu \mathrm{g} \mathrm{L}^{-1}$ in the sample solution. The linear calibration equation without preconcentration was $\mathrm{A}=$ $0.0534 \mathrm{C}+0.0023$ with a correlation coefficient of 0.9996. The experimental enrichment factor was calculated by the slope ratio of the calibration equation obatained with preconentration of $8.0 \mathrm{~mL}$ solution and without preconcentration. The theoretical preconcentration factor was calculated by the ratio of volumes of the sample (8.0 $\mathrm{mL})$ and the final solutions $(0.2 \mathrm{~mL})$. The relative error was $-0.5 \%$.

The limits of detection (LOD) and quantification (LOQ) were calculated as three and ten times respectively of the standard deviation of eleven blank readings divided by the slope of the calibration curve after preconcentration.

The sampling frequency was calculated for four samples centrifuged and evaporated simultaneously. In DLLME studies, another important analytical figure is consumptive index calculated by the ratio of the volume of solution of the metal used in the preconcentration and enrichment factor. ${ }^{28}$ The consumptive index is defined as the sample volume consumed to achieve a unit of EF. A summary of the analytical characteristics of dispersive liquid-liquid microextraction for gold using Rhodamine B as ion pair agent is presented in Table 6.

The precision was studied by processing six replicate standard solutions of gold and the relative standard deviation (RSD) for $10 \mu \mathrm{g} \mathrm{L} \mathrm{L}^{-1}$ of $\mathrm{Au}(\mathrm{III})$ ions was $\pm 3.2 \%$. It was changed from the range of 0.4 to $6.8 \%$ for real samples (Table 6).
Table 6. Analytical figures of the IP-DLLME-MIS-FAAS method for determination of gold

\begin{tabular}{|c|c|}
\hline Characteristics & Figures of merit \\
\hline Linear range with DLLME $\left(\mu \mathrm{g} \mathrm{L}^{-1}\right)$ & $8-100$ \\
\hline Linear range without DLLME $\left(\mu \mathrm{g} \mathrm{mL}^{-1}\right)$ & $0.25-10$ \\
\hline Experimental enrichment factor & 39.8 \\
\hline Theoretical enrichment factor & 40.0 \\
\hline Limit of detection (LOD, $\left.\mu \mathrm{g} \mathrm{L}^{-1}\right)(3 \sigma, \mathrm{n}: 12)$ & 1.8 \\
\hline Limit of quantification (LOQ, $\mu \mathrm{g} \mathrm{L}^{-1}$ ) & 6.2 \\
\hline Precision (RSD, \%) (Au(III): $\left.10 \mu \mathrm{g} \mathrm{L}^{-1}, \mathrm{n}: 6\right)$ & \pm 3.2 \\
\hline Sample volume $(\mathrm{mL})$ & 8.0 \\
\hline Sampling frequency $\left(\right.$ samples $\mathrm{h}^{-1}$ ) & 24 \\
\hline Consumptive index $(\mathrm{mL})$ & 0.20 \\
\hline
\end{tabular}

\section{6. Analytical Application}

The proposed DLLME method was applied to the extraction of gold in water samples (tap water and waste water), electrolyte solution from a copper electrolysis unit and nickel plated wire samples having different and complicated matrix. The validity and reliability of IP-DLLME method was tested by the analysis of the samples spiked with the known amount of gold (no certified reference material was available). The results in Table 7 reveal that recoveries of spiked samples were in the range of 94-98\%, indicating the good validity and reliability of the proposed IP-DLLME method for the analysis of a wide range of samples.

Table 7. Determination of gold in real samples(n:4)

\begin{tabular}{|c|c|c|c|c|}
\hline \multirow{2}{*}{ Samples } & \multicolumn{2}{|c|}{ Amount of gold, $\mu \mathrm{g}$} & \multirow[b]{2}{*}{ Recovery, \% } & \multirow[b]{2}{*}{ RSD, \% } \\
\hline & Added & Found $^{\mathrm{a}}$ & & \\
\hline \multirow[t]{3}{*}{ Tap water } & - & n.d. & - & - \\
\hline & 0.50 & $0.49 \pm 0.01$ & 98.0 & 2.0 \\
\hline & 1.00 & $0.96 \pm 0.04$ & 96.0 & 4.2 \\
\hline \multirow{3}{*}{$\begin{array}{l}\text { Industrial } \\
\text { wastewater }\end{array}$} & - & n.d. & - & - \\
\hline & 0.62 & $0.58 \pm 0.03$ & 93.5 & 5.2 \\
\hline & 1.25 & $1.21 \pm 0.03$ & 96.8 & 2.5 \\
\hline \multirow{3}{*}{$\begin{array}{l}\text { Copper } \\
\text { electrolysis } \\
\text { solution }^{\mathrm{b}}\end{array}$} & - & n.d. & - & - \\
\hline & 0.62 & $0.59 \pm 0.04$ & 95.2 & 6.8 \\
\hline & 1.25 & $1.20 \pm 0.08$ & 96.0 & 6.7 \\
\hline \multirow{3}{*}{$\begin{array}{l}\text { Nickel-plated } \\
\text { wire }\end{array}$} & - & n.d. & - & - \\
\hline & 1.25 & $1.19 \pm 0.02$ & 95.2 & 1.7 \\
\hline & 2.50 & $2.35 \pm 0.01$ & 98.0 & 0.4 \\
\hline
\end{tabular}

${ }^{a}$ Mean \pm standard deviation. ${ }^{b}$ Electrolysis solution was diluted 200fold because of high copper content as $7210 \mathrm{mg} \mathrm{L}^{-1}$, determined by flame AAS.

\section{Conclusion}

In this study, a novel analytical method using ion pair-dispersive liquid-liquid microextraction combined with microsample injection system-flame atomic absorp- 
Table 8. Comparative data from some recent studies on preconcentration of gold ions

\begin{tabular}{lcccccc}
\hline Analytical System & LOD, $\boldsymbol{\mu g ~ L}^{-\mathbf{1}}$ & EF & RSD, $\%$ & Sample Vol., $\mathbf{~ m L}$ & Acidity & Refs. \\
\hline Coprecipitation/FAAS & 1.5 & 25 & $<10 \%$ & 50 & $\mathrm{pH}=4$ & 29 \\
SPE/FAAS & 16.6 & 200 & $<6 \%$ & 1000 & $1-2.5 \mathrm{M} \mathrm{HNO}_{3}$ & 3 \\
SPE/FAAS & 1.61 & 31 & $<5 \%$ & 250 & $\mathrm{pH}=4$ & 4 \\
SPE/FAAS & 0.15 & 75 & 3.1 & 150 & $\mathrm{pH}=2$ & 30 \\
SPE/FAAS & 30 & 250 & 6.1 & 1000 & $\mathrm{pH}=6$ & 31 \\
IL-LLE/FAAS & 72 & 10 & $<2.48 \%$ & 10 & $1 \mathrm{M} \mathrm{HCl}$ & 32 \\
DLLME/ETAAS & 5 & 388 & 4.2 & 10 & $0.5 \mathrm{M} \mathrm{HCl}$ & 33 \\
DLLME/FAAS & 0.4 & 94 & 2 & 10 & $2.5 \mathrm{M} \mathrm{HCl}$ & 34 \\
DLLME/FAAS & 0.1 & $28.6^{*}$ & 2.1 & 10 & $\mathrm{pH}=2.3$ & 20 \\
IP-DLLME/MIS-FAAS & 1.8 & 40 & 3.2 & 8 & $1.0 \mathrm{M} \mathrm{HCl}$ & This work \\
\hline
\end{tabular}

LOD: limit of detection, EF: enrichment factor, RSD: relative standard deviation, SPE: solid phase extraction, IL-LLE: ionic liquid-liquid liquid extraction.*It was found by the ratio of volumes of the sample $(10.0 \mathrm{~mL})$ and the final solution $(350 \mu \mathrm{L})$.

tion spectrometry (IP-DLLME/MIS-FAAS) has been proposed for the extraction and determination of gold(III) ions. The proposed method allowed tackling the determination of gold in samples having complicated matrix. The method showed high tolerance to the interferences from the matrix ions. The good figures of merit for method were obtained. Table 8 compares the characteristic analytical figures of the proposed procedure with those reported in literature. In general, the limit of detection, enrichment factor and precision obtained by the proposed procedure are comparable to the listed preconcentration methods, and the sample volume used in this study is less that the methods listed in Table 8. The proposed method is simple, efficient, rapid, and inexpensive and the consumption of organic solvents is lower than in other conventional sample preparation methods. In addition, it may be concluded that IPDLLME is a good bridge between the flame atomic absorption spectrometry with microsample injection system and the samples containing low concentration of analytes.

\section{Acknowledgement}

The authors are thankful to the Scientific Research Projects(SRP) Coordination Unit of Pamukkale University for the financial support of this study (Project number: 2010FBE044).

\section{References}

1. K. Pyrzynska, Anal. Chim. Acta., 2012, 741, 9-14. http://dx.doi.org/10.1016/j.aca.2012.06.044

2. L. Medved, M. Bujdos, P. Matus, J. Kubova, Anal. Bioanal. Chem., 2004, 379, 60-65. http://dx.doi.org/10.1007/s00216-004-2538-9

3. H. B. Senturk, A. Gundogdu, V. N. Bulut, C. Duran, M. Soylak, L. Elci, M. Tufekci, J. Hazard. Mater, 2007, 149, 317- 323. http://dx.doi.org/10.1016/j.jhazmat.2007.03.083
4. M. Tuzen, K. O. Saygi, M. Soylak, J. Hazard. Mater., 2008, 156, 591-595. http://dx.doi.org/10.1016/j.jhazmat.2007.12.062

5. J. Hassan, M. Shamsipur, M.-H. Karbasi, Microchem. J., 2011, 99, 93-96. http://dx.doi.org/10.1016/j.microc.2011.04.003

6. S. Kagaya, D. Takata, T. Yoshimori, T. Kanbara, K. Tohda, Talanta, 2010, 80, 1364-1370. http://dx.doi.org/10.1016/j.talanta.2009.09.037

7. P. Pohl, W. Zyrnicki, J. Anal. At. Spectrom., 2003, 18, 798801. http://dx.doi.org/10.1039/b301921g

8. L. Tavakoli, Y. Yamini, H. Ebrahimzadeh, A. Nezhadali, S. Shariati, F. Nourmohammadian, J. Hazard. Mater, 2008, 152(2), 737-743. http://dx.doi.org/10.1016/j.jhazmat.2007.07.039

9. L. Elçi, S. Işildar, M. Doğan, Anal. Chim. Acta., 1994, 293, 319-324. http://dx.doi.org/10.1016/0003-2670(94)85037-2

10. E. A. Moawed, M. F. El-Shahat, Anal. Chim. Acta., 2013, 788, 200-207. http://dx.doi.org/10.1016/j.aca.2013.05.064

11. C. Zeng, L. Tang, Anal. Lett., 2013, 46, 1442-1453. http://dx.doi.org/10.1080/00032719.2013.766799

12. W. S. El-Naggar, T. A. Lasheen, E.-S. A. Nouh, A. K. Ghonaim, Cent. Eur. J. Chem., 2010, 8(1), 34-40. http://dx.doi.org/10.2478/s11532-009-0093-0

13. J. Jiang, Y. He, H. Gao, J. Wu, Solvent Extr. Ion Exch., 2005, 23, 113-129. http://dx.doi.org/10.1081/SEI-200044389

14. L. Elçi, D. Şahan, A. Elçi, M. Soylak, Environ. Monit. Assess., 2007, 132(1-3), 331-338. http://dx.doi.org/10.1007/s10661-006-9537-6

15. M. Rezaee, Y. Assadi, M.-R. M. Hosseini, E. Aghaee, F. Ahmadi, S. Berijani, J. Chromatogr. A., 2006, 1116(1-2), 1-9. http://dx.doi.org/10.1016/j.chroma.2006.03.007

16. S. Dadfarnia, A. M. Haji Shabani, Anal. Chim. Acta., 2010, 658, 107-119.

http://dx.doi.org/10.1016/j.aca.2009.11.022 
17. A. N. Anthemidis, K.-I. G. Ioannou, Talanta, 2009, 80(2), 413-421. http://dx.doi.org/10.1016/j.talanta.2009.09.005

18. M. S. El-Shahawi, A. S. Bashammakh, S. O. Bahaffi, Talanta, 2007, 72(4), 1494-1499. http://dx.doi.org/10.1016/j.talanta.2007.01.057

19. M. Shamsipur, M. Ramezani, Talanta, 2008, 75(1), 294-300. http://dx.doi.org/10.1016/j.talanta.2007.11.009

20. A. Iraji, D. Afzali, A. Mostafavi, Intern. J. Environ. Anal. Chem., 2013, 93, 315-324. http://dx.doi.org/10.1080/03067319.2011.609937

21. Z. Marczenko, Spectrophotometric Determination of Elements, 3rd ed., Ellis Horwood, Chichester, UK, 1986.

22. J. Tournebize, A. Sapin-Minet, R. Schneider, A. Boudier, P. Maincent, P. Leroy, Talanta, 2011, 83, 1780-1783. http://dx.doi.org/10.1016/j.talanta.2010.12.005

23. Tournebize, A. Sapin-Minet, R. Schneider, A. Boudier, P. Maincent, P. Leroy, Talanta, J. A. Baig, A. Hol, A. Akdogan, A. Arslan Kartal, U. Divrikli, T. G. Kazi, L. Elci, J. Anal. At. Spectrom,. 2012, 27, 1509-1517. http://dx.doi.org/10.1039/c2ja30107e

24. V. Ponnusami, V. Krithika, R. Madhuram, S. N. Srivastava, J. Hazard. Mater., 2007, 142, 397-403. http://dx.doi.org/10.1016/j.jhazmat.2006.08.040

25. D. Bingol, N. Tekin, M. Alkan, Appl. Clay Sci., 2010, 50, 315-321.

http://dx.doi.org/10.1016/j.clay.2010.08.015
26. K. Palanikumar, J. P. Dawim, J. Mater. Process. Technol., 2009, 209, 511-519. http://dx.doi.org/10.1016/j.jmatprotec.2008.02.020

27. F. Kamarei, H. Ebrahimzadeh, Y. Yamini, Talanta, 2010, 83, 36-41. http://dx.doi.org/10.1016/j.talanta.2010.08.035

28. P. X. Baliza, L. S. G. Teixeira, V. A. Lemos, Microchem. J., 2009, 93, 220-224. http://dx.doi.org/10.1016/j.microc.2009.07.009

29. M. Soylak, M. Tuzen, J. Hazard. Mater., 2008, 152, 656661. http://dx.doi.org/10.1016/j.jhazmat.2007.07.027

30. P. Liang, E. Zhao, Q. Ding, D. Du, Spectrochim. Acta, Part $B, 2008,63,714-717$. http://dx.doi.org/10.1016/j.sab.2008.04.002

31. T. Shamspur, A. Mostafavi, J. Hazard. Mater., 2008, 168, 1548-1553. http://dx.doi.org/10.1016/j.jhazmat.2009.03.028

32. O. Sha, X. Zhu, Anal. Lett., 2014, 47, 1052-1062. http://dx.doi.org/10.1080/00032719.2013.860539

33. M. Shamsipur, M. Ramezani, Talanta 2008, 75, 294-310. http://dx.doi.org/10.1016/j.talanta.2007.11.009

34. C. Ozdemir, S. Sacmac1, S. Kartal, M. Sacmac1, J. Ind. Eng. Chem., 2014, http://dx.doi.org/10.1016/j.jiec.2014.01.005.

\section{Povzetek}

Razvili smo novo ionsko-parno disperzivno mikroekstrakcijo tekoče-tekoče (IP-DLLME) za zlato, ki ji sledi določitev z mikrovzorčevalnim injektorskim sistemom in plamensko atomsko absorpcijsko spektrometrijo (MIS-FAAS). Ekstrakcijska metoda je osnovana na reakciji anionskega tetrakloro zlatovega(III) kompleksa s kationsko obliko Rodamina $\mathrm{B}$, pri čemer nastane vijoličast ionsko-parni kompleks, ki ga ekstrahiramo iz $1,0 \mathrm{~mol} \mathrm{~L}^{-1}$ raztopine $\mathrm{HCl}(8,0 \mathrm{~mL})$ $\mathrm{v}$ fine kapljice kloroforma $(500 \mu \mathrm{L})$. Za optimizacijo glavnih parametrov, ki jih je potrebno kontrolirati pri DLLME, smo uporabili Plackett-Burman-ov eksperimentalni načrt in MINITAB statistični program. Po optimizaciji ekstrakcijskih pogojev smo za zlato dobili kvantitativne izkoristke in predkoncentracijski faktor 40, mejo zaznave (LOD) $1,8 \mu \mathrm{g}$ $\mathrm{L}^{-1}$ in relativni standardni odmik manj kot $6,8 \%$. Predlagano metodo smo uspešno uporabili za predkoncentracijo in določitev zlata v nekaterih vzorcih, kot so vodovodna voda, odpadna voda, raztopina za elektrolizo bakra in ponikljana bakrova žica. 